\title{
PROSES PEMBUKTIAN PERKARA PIDANA DALAM PERSIDANGAN YANG DILAKUKAN SECARA ONLINE
}

\author{
Ronaldo Naftali, ${ }^{1}$ Aji Lukman Ibrahim, ${ }^{2}$ \\ ${ }^{1}$ Fakultas Hukum Universitas Pembangunan Nasional Veteran Jakarta \\ 2 Fakultas Hukum Universitas Pembangunan Nasional Veteran Jakarta \\ Email : adjie_loekman@upnvj.ac.id
}

\begin{abstract}
The Law of Evidence in Criminal Law is crucial in order to uncover a criminal act. The Public Prosecutor ought to prove each of the charges supported by sufficient evidences. Most of the trial during the Covid-19 Pandemic should be conducted online. This change is necessary to keep in line with the Covid-19 health protocol and also to support the industrial revolution. The purpose of this study is to determine the evidentiary process carried out by the Public Prosecutor in online trials and to discover the ideal way to guaranteeing the network security policies in future online trials. This research is considered as a normative juridical research equipped with interviews using a statutory approach, a case approach and a conceptual approach. Sources of data obtained from secondary data which includes primary, secondary, and tertiary legal materials. The results of the study shows that in the online trial, the facilities and also infrastructure for judges, prosecutors, advocates I defendants to carry out online trials to the fullest exactly like an offline trial. Qualified human resources are also needed in the trial process through Teleconference which controls directly to support the smooth online trial process. In the future evidence process, it is necessary to guarantee the security of a special website or website used in conducting trials through Teleconference in order to anticipate the existence of illegal hackers who are able to intervene in the examination of witness statements and interfere with the trial process, especially at the stage of the evidence examination process.
\end{abstract}

Keywords: Covid-19; Public Prosecutor; Proof; Online Trial

\begin{abstract}
Abstrak
Hukum Pembuktian dalam Pidana menjadi hal yang sangat penting untuk mengungkap suatu tindak pidana. Jaksa Penuntut Umum harus membuktikan setiap dakwaannya yang didukung alat bukti yang cukup. Di masa pandemi Covid-19 seperti ini, membuat persidangan dilakukannya secara online. Perubahan itu menjadi kebutuhan revolusi industri serta tetap melaksanakan protokol kesehatan. Tujuan penelitian ini untuk mengetahui proses pembuktian yang dilakukan oleh Jaksa Penuntut Umum dalam persidangan online dan untuk mengetahui pengaturan ideal mengenai jaminan keamanan jaringan yang digunakan dalam persidangan online di masa mendatang. Penelitian ini merupakan penelitian yuridis normatif dilengkapi dengan wawancara dengan menggunakan pendekatan perundang-undangan, pendekatan kasus dan pendekatan konseptual. Sumber data diperoleh dari data sekunder yang meliputi bahan hukum primer, sekunder, dan tersier. Hasil dari penelitian meunjukkan bahwa dalam persidangan online sarana dan prasarana bagi Hakim, JPU, Advokat/Terdakwa guna melaksanakan persidangan online secara maksimal layaknya persidangan biasa. Sumber daya manusia yang mempuni juga diperlukan dalam proses persidangan melalui Teleconference yang mengontrol langsung untuk mendukung kelancaran proses persidangan online. Dalam proses pembuktian di masa mendatang perlu adanya jaminan keamanan situs atau website khusus yang digunakan dalam pelaksanaan persidangan melalui Teleconference guna
\end{abstract}


mengantisipasi adanya peretas ilegal (hacker) yang dapat mengintervensi pemeriksaan keterangan saksi dan menggangu jalannya proses persidangan khususnya dalam tahap proses pemeriksaan pembuktian.

Kata Kunci: Covid-19; Jaksa Penuntut Umum; Pembuktian; Persidangan Online

\section{Pendahuluan}

\subsection{Latar Belakang}

Hukum menjadi suatu alat yang mengatur kehidupan masyarakat mengenai suatu tindakan apa yang dilarang dan apa yang tidak dilarang. Ada beberapa pembagian Hukum Pidana, salah satunya pembagian hukum pidana materil dan hukum pidana formil. Hukum pidana materil merupakan isi atau substansi hukum pidana itu. Hukum pidana dalam hal ini bermakna abstrak atau dalam keadaan diam. Hukum pidana formil atau Hukum Acara Pidana bersifat nyata atau konkret. Dalam hal ini, hukum pidana dalam keadaan bergerak atau dijalankan atau berada dalam sutau proses. ${ }^{1}$ Dalam konteks ini hukum pidana formil sering juga disebut sebagai hukum acara.

Menurut Van Bemmelen, Ilmu Hukum Acara Pidana mempelajari peraturanperaturan yang diciptakan oleh negara, karena adanya dugaan terjadi pelanggaran undangundang pidana. ${ }^{2}$ Negara melalui alat-alatnya menyidik kebenaran dan sedapat mungkin menyidik pelaku perbuatan itu serta mengambil tindakan-tindakan jika diperlukan guna menangkap pelaku bahkan dapat langsung dilakukan penahanan. Setelah itu, dilakukan pengumpulan bahan-bahan bukti (bewijsmateriaal) yang telah diperoleh pada penyidikan kebenaran guna dilimpahkan kepada Hakim dan kemudian membawa terdakwa ke depan Hakim tersebut, kemudian Hakim memberi keputusan tentang terbukti tidaknya perbuatan yang dituduhkan kepada terdakwa dan untuk menjatuhkan pidana atau tindakan tata tertib, lalu adanya upaya hukum untuk melawan keputusan tersebut dan akhirnya melaksanakan keputusan tentang pidana dan tindakan tata tertib itu. ${ }^{3}$

Dalam proses acara pidana, tahap pembuktian menjadi hal yang vital untuk menentukan terbukti atau tidaknya suatu tindak pidana yang terjadi. Hukum pembuktian merupakan sebagian dari Hukum Acara Pidana, sumber hukum yang utama adalah Undang-Undang Nomor 8 Tahun 1981 tentang Hukum Acara Pidana atau KUHAP, Lembaran Negara Republik Indonesia Tahun 1981 Nomor 76 dan penjelasannya yang dimuat dalam Tambahan Lembaran Negara Republik Indonesia Nomor 3209, dan terdapat sumber hukum pembuktian lain seperti undang-undang, doktrin atau pendapat para ahli hukum dan Yurisprudensi/Putusan Pengadilan. ${ }^{4}$ Dalam KUHAP bagian kekempat mengenai pembuktian dan putusan dalam acara pemeriksaan biasa, diatur mengenai sistem

1 Andi Hamzah, (2010), Asas-Asas Hukum Pidana edisi revisi 2008, Jakarta, hlm. 2.

2 Ibid, hlm. 3.

${ }^{3}$ Ibid.

4 Alfitra, (2017) Hukum Pembuktian Dalam Beracara Pidana, Perdata dan Korupsi di Indonesia, Jakarta, Raih Asa Sukses, hlm. 22. 
pembuktian, macam-macam alat bukti dan kekuatan pembuktian. Sistem pembuktian diatur dalam Pasal 183 KUHAP, macam-macam alat bukti diatur dalam Pasal 184 KUHAP dan kekuatan pembuktian diatur dalam Pasal 185 sampai Pasal 189 KUHAP. ${ }^{2}$ Proses pembuktian menjadi hal yang vital bagi Hakim untuk menentukan dan menjatuhkan putusan terhadap perkara tindak pidana. Jaksa Penuntut Umum harus membuktian setiap dakwaannya terhadap terdakwa dengan beberapa alat bukti sesuai KUHAP sekalipun persidangan dilakukan secara online.

Penulisan tertarik untukmelaukan penelitian ini karena hal ini berkaitan dengan semakin berkembangnya era digital ditengah masyarakat serta kondisi pandemi Covid-19 yang memaksa pola hidup masyarakat berubah termasuk proses persidangan pidana.

\subsection{Rumusan Masalah}

Sebagai pijakan dan sekaligus juga sebagai pembatasan dalam pembahasan tulisan ini dikemukan rumusan masalah sebagai berikut:

1. Bagaimana proses pembuktian yang dilakukan oleh Jaksa Penuntut Umum dalam persidangan online?

2. Bagaimana idealnya pengaturan mengenai jaminan keamanan jaringan yang digunakan dalam persidangan online di masa mendatang?

\section{Metode Penelitian}

Penelitian ini termasuk ke dalam penelitian yuridis normatif dilengkapi dengan wawancara, berdasarkan perumusan masalah dan tujuan penelitian di atas, maka metode pendekatan yang digunakan adalah pendekatan Perundang-undangan yaitu pendekatan tentang perundang-undangan yang berkaitan langsung dengan topik dan pembahasan dalam hal ini penerapan pembuktian yang dilakukan oleh Jaksa Penuntut Umum dalam proses sidang secara online dan menggunakan metode pendekatan kasus dan pendekatan konseptual.

Sumber data dalam penelitian ini menggunakan data sekunder yang meliputi bahan hukum primer, bahan hukum sekunder, dan bahan hukum tersier. Teknik analisis data secara kualitatif yang bersifat deskriptif analitisberdasarkan bahan hukum primer, bahan hukum sekunder, dan bahan hukum tersier serta hasil wawancara.

\section{Hasil dan Pembahasan}

\subsection{Proses Pembuktian yang Dilakukan oleh Jaksa Penuntut Umum dalam Persidangan online}

Hukum pembuktian meliputi hal yang sangat luas, pembuktian meliputi segala sesuatu yang berkaitan dengan pembuktian itu sendiri. Dimulai dari tahap pengumpulan

${ }^{5}$ Hari Sasangka dan Lily Rosita, (2003) Hukum Pembuktian Dalam Perkara Pidana (Untuk Mahasiswa dan Praktisi), Bandung, Mandar Maju, hlm. 14. 
alat bukti, penyampaian bukti sampai ke pengadilan, penilaian terhadap setiap bukti sampai pada beban pembuktian di pengadilan. ${ }^{6}$ Perkembangan hukum pembuktian sangat berpengaruh bagi perkara yang sedang ditangani dan bukti yang dimiliki. Berkembangnya teknologi dan ilmu pengetahuan akan mempengaruhi pada hukum pembuktian, termasuk dalam proses pembuktian sidang online. Hukum pembuktian bukanlah sistem yang teratur, kuat atau lemahnya pembuktian tergantung pada kesesuaian antara fakta yang satu dengan fakta yang lain yang dapat dibuktikan dan diiyakinkan kepada Hakim. Ada kalanya material facts atau fakta-fakta pokok yang harus dibuktikan pada kenyataannya tidak bisa meyakinkan Hakim. Oleh karena itu, pembuktian atas fakta tersebut dianggap lemah. ${ }^{7}$ Bewijskracht dapat diartikan sebagai kekuatan pembuktian masing-masing alat bukti dalam rangkaian penilaian terbuktinya suatu dakwaan. Penilaian tersebut merupakan otoritas Hakim. Hakim yang menentukan dan menilai kesesuaian antara alat bukti yang satu dengan alat bukti yang lain. ${ }^{8}$

Kekuatan pembuktian juga terletak pada bukti yang diajukan mengenai relevansi atau tidak dengan perkara yang disidangkan. Ketika bukti itu mempunyai relevansi selanjutnya mengarah kepada bukti tersebut dapat diterima atau tidak. Dalam Hukum Acara Pidana, kekuatan semua alat bukti pada hakekatnya sama, tidak ada satu alat bukti yang melebihi alat bukti yang lain. Alat bukti dalam hukum pidana tidak mengenal hierarki, hanya saja terdapat ketentuan-ketentuan yang mensyaratkan keterkaitan antara bukti yang satu dengan bukti yang lain. Dalam Hukum Acara Pidana terdapat bukti yang bersifat sebagai pelengkap, yaitu bukti yang timbul dari bukti lain. ${ }^{9}$ Salah satu ketentuan yang mengatur bagaimana caranya aparat penegak hukum melaksanakan tugas dibidang represif adalah Hukum Acara Pidana. Hukum Acara Pidana yang mempunyai tujuan yaitu untuk mencari dan mendekati kebenaran materiil. Kebenaran materiil ialah kebenaran yang selengkap-lengkapnya dari suatu perkara pidana dengan menerapkan ketentuan Hukum Acara Pidana secara jujur dan tepat dengan tujuan untuk mencari siapakah pelaku yang dapat didakwakan melakukan suatu pelanggaran hukum, dan selanjutnya meminta pemeriksaan dan putusan dari pengadilan guna menentukan apakah terbukti bahwa suatu tindak pidana telah dilakukan dan apakah orang yang didakwa itu dapat dimintai pertanggungjawaban. ${ }^{10}$

Dalam konteks Hukum Acara Pidana di Indonesia, untuk menjatuhkan pidana terhadap terdakwa paling tidak harus ada dua alat bukti ditambah keyakinan Hakim. Hal ini berarti, untuk menjatuhkan pidana bewijs minimum adalah dua alat bukti. Ketentuan perihal minimum bukti ini terdapat dalam pasal 183 KUHAP sebagaimana yang telah

${ }^{6}$ Eddy O.S. Hiariej, (2012), Teori \& Hukum Pembuktian, Jakarta, Erlangga, hlm. 14.

${ }^{7}$ Ibid, hlm. 15.

8 Ibid, hlm. 25.

${ }^{9}$ Ibid, hlm. 26.

${ }^{10}$ Bastianto Nugroho, "Peranan Alat Bukti Dalam Perkara Pidana Dalam Putusan Hakim Menurut Kuhap", Yuridika, Volume 32 ,Nomor 1, Januari Tahun 2017, hlm. 19. 
dijelaskan di atas tentang negatief wettelijk bewijstheorie yang dianut di Indonesia.11 Pembuktian dengan minimal dua alat bukti dan keyakinan Hakim adalah hal penting dalam penjatuhan putusan perkara terhadap terdakwa, maka Jaksa Penuntut Umum harus membuktikan dakwaan disertai alat-alat bukti yang diperlukan. Pembuktian adalah ketentuan-ketentuan yang berisi penggarisan dan pedoman tentang cara-cara yang dibenarkan undang-undang membuktikan kesalahan yang didakwakan kepada Terdakwa. Sistem pembuktian yang dianut KUHAP itu disebut negatief wettelijk, wettelijk atau menurut undang-undang karena untuk pembuktian undang-undanglah yang menentukan tentang jenis dan banyaknya alat bukti yang harus ada. ${ }^{12}$

Alat bukti adalah segala sesuatu yang ada hubungannya dengan suatu perbuatan, di mana dengan alat-alat bukti tersebut dapat digunakan sebagai bahan pembuktian guna menimbulkan keyakinan Hakim atas kebenaran adanya suatu tindak pidana yang telah dilakukan oleh terdakwa. Pengajuan alat bukti yang sah menurut undang-undang di dalam persidangan dilakukan oleh Penuntut Umum dengan tujuan untuk membuktikan dakwaannya, terdakwa atau Penasihat Hukum jika ada alat bukti yang bersifat meringankan atau membebebaskan terdakwa dari segala tuntutan hukum. Pada dasarnya yang mengajukan alat bukti dalam persidangan adalah Penuntut Umum (alat bukti yang memberatkan/acharge) dan terdakwa atau Penasihat Hukum (jika ada alat bukti yang bersifat meringankan/adecharge). ${ }^{13}$

Terdakwa tidak dibebani kewajiban pembuktian, hal ini erat hubungannya dengan asas praduga tak bersalah (Pasal 66 KUHAP), yang pada prinsipnya membuktikan kesalahan terdakwa itu adalah Penuntut Umum. Hakim dalam proses persidangan pidana bersifat aktif, maka apabila dirasa perlu Hakim dapat memerintahkan Penuntut Umum untuk menghadirkan saksi tambahan dan juga apabila dirasa oleh Hakim cukup, maka Hakim dapat menolak alat-alat bukti yang diajukan dengan alasan Hakim sudah menganggap tidak perlu karena sudah cukup meyakinkan. Hakim juga mengetahui bahwa pengajuan bukti merupakan hak dari Penuntut Umum dan terdakwa atau Penasihat Hukum. Oleh karena itu, penolakan pengajuan alat bukti harus benar-benar dipertimbangkan dan beralasan yang kuat. ${ }^{14}$ Alat-alat bukti menjadi krusial karena membantu untuk mendeskripsikan suatu tindak pidana supaya menjadi terang-benderang bagi Hakim, Jaksa Penuntut Umum dan Terdakwa atau Penasihat Hukum.

11 Op. Cit.

12 Salut Murniasih, "Pembuktian Berdasar Keterangan Saksi Verbalisan Akibat Pencabutan Keterangan Terdakwa Di Persidangan Dalam Perkara Persetubuhan Terhadap Anak (Studi Putusan Pengadilan Negeri Brebes Nomor 27/Pid.Sus/2016/Pn.Bbs)", Jurnal Verstek, Volume 7, Nomor 2, Bagian Hukum Acara Universitas Sebelas Maret, hlm. 194.

${ }^{13}$ Loc.Cit, Alfitra, hlm. 23.

${ }^{14} \mathrm{Ibid}, \mathrm{hlm} .24$. 
Pembuktian memiliki pengaruh dalam proses pemeriksaan persidangan, bagi Penuntut Umum pembuktian adalah usaha untuk meyakinkan Hakim, yakni berdasarkan alat bukti yang ada agar menyatakan seorang terdakwa bersalah sesuai dengan surat atau catatan dakwaan dan bagi terdakwa atau Penasihat Hukum pembuktian merupakan usaha untuk meyakinkan Hakim, yakni berdasarkan alat bukti yang ada agar menyatakan seorang terdakwa dibebaskan atau dilepaskan dari tuntutan hukum atau meringankan pidananya. ${ }^{15}$ Untuk itu, terdakwa atau Penasihat Hukum harus mengajukan alat-alat bukti yang menguntungkan atau meringankan pihaknya (bukti kebalikan). Hakim atas dasar pembuktian tersebut, baik alat bukti dari Penuntut Umum dan alat bukti dari Penasihat Hukum menjadi dasar untuk membuat keputusan. ${ }^{16}$ Keterangan seorang saksi sangat penting dalam proses penyelesaian perkara. Pembuktian yang dilakukan mengenai argumentasi atau dalil yang didasarkan atas alat-alat bukti yang diajukan dalam pemeriksaan perkara, merupakan bagian yang paling penting dalam hukum acara di pengadilan. Di dalamnya terkait erat persoalan hak-hak hukum dan bahkan hak asasi setiap orang atau pihak-pihak yang dipersangkakan telah melakukan pelanggaran hukum. ${ }^{17}$ Tetapi, keterangan saksi bukanlah satu-satunya instrumen dalam penyelesaian perkara. Terdapat empat alat bukti sah lainnya yang juga diatur secara tegas dalam hukum positif Indonesia. Suatu perkara akan buntu apabila tidak ada satu pun alat bukti yang dapat mendukung atau hanya terdapat alat bukti saksi untuk menyelesaikan perkara tersebut. ${ }^{18}$

Dalam kondisi pandemi Covid-19 seperti ini memaksa untuk proses persidangan yang biasa berubah menjadi sistem persidangan online (Teleconference). Pembuktian secara teleconference sebenarnya merupakan sebuah dualisme yang dianut di dalam Hukum Acara Pidana, pembuktian secara teleconference dapat dimasukkan sebagai alat bukti elektronik sebagaimana diatur didalam Undang-Undang Nomor 11 Tahun 2008 tentang Informasi dan Transaksi elektronik namun juga dapat berupa keterangan saksi. Di dalam Prakteknya, Pembuktian secara Teleconference biasanya dipergunakan dalam hal pemberian keterangan saksi. ${ }^{19}$

\subsection{Pengaturan Ideal Mengenai Jaminan Keamanan Jaringan yang Digunakan dalam Persidangan Online di Masa Mendatang}

Kebijakan hukum pidana dalam pemberian keterangan saksi melalui media teleconference saat ini, di mana menurut hukum saksi tersebut harus memenuhi syarat-syarat sebagai Saksi, yaitu harus mengucapkan sumpah atau janji lebih

${ }^{15} \mathrm{Ibid}, \mathrm{hlm} .25$.

${ }^{16} \mathrm{Ibid}$.

17 Jemmy Mariangi, “Tinjauan Yuridis Tentang Pemeriksaan Saksi Dipersidangan Melalui Teleconference", Jurnal Ilmu Hukum Legal Opinion, Edisi 4, Volume 1, Tahun 2013, hlm. 6.

18 Ni Made Rit Meidyana, Ida Bagus Wyasa Putra, (2019) "Keabsahan Pemeriksaan Saksi Melalui Teleconference Dalam Sidang Tindak Pidana Korupsi", Program Kekhususan Peradilan, hlm. 5.

${ }^{19}$ Swindy A.J. Tintingon, "Kesaksian Saksi Melalui Teleconference Dalam Persidangan Di Pengadilan", Lex et Societatis, Volume 2, Nomor 8, September - November Tahun 2014, hlm. 63. 
dahulu sesuai Pasal 160 ayat (3) KUHAP jo. Pasal 185 ayat (7) KUHAP, Keterangan saksi dinyatakan secara lisan melalui alat komunikasi audio visual / teleconference di muka sidang pengadilan yang merupakan perluasan dari Pasal 185 ayat (1) KUHAP, Isi keterangan harus mengenai hal yang saksi lihat, dengar, dan alami, serta menyebutkan alasan dari pengetahuannya itu sesuai Pasal 1 angka 27 KUHAP dan Keterangan saksi tersebut saling bersesuaian satu sama lain sesuai Pasal 185 ayat (6) KUHAP. ${ }^{20}$

Dalam proses pembuktian, Jaksa Penuntut Umum harus meyakinkan setiap dakwaan yang didukung oleh alat-alat bukti yang sesuai dengan perkara yang ada. Hal ini menjadi sebuah tantangan baru bagi seorang Jaksa Penuntut Umum yang biasa disebut sebagai ahli pembuktian, karena di dalam proses pembuktian itulah yang menjelaskan peristiwa tindak pidana yang sebenarnya terjadi. Dalam proses persidangan biasa, Jaksa masih dapat menjelaskan secara detail dan rinci mengenai pembuktian atas perkara tersebut, tetapi jika dalam proses persidangan secara online atau Teleconference Jaksa berkewajiban untuk membuktikan setiap dakwaannya terhadap terdakwa melalui virtual dan yang menjadi kendala adalah jaringan internet yang tidak stabil sehingga menggangu proses pembuktian dalam acara pidana tersebut. ${ }^{21}$

Teleconference tidak diatur dalam KUHAP karena pembuat Undang-Undang pada waktu itu tentunya tidak menyadari adanya revolusi teknologi informasi dan komunikasi yang sedemikian pesat sehingga KUHAP tidak mampu mengantisipasinya. Apabila mengacu secara kaku/formal legalistic memang teleconference tidak sesuai dengan ketentuan Pasal 160 ayat (1) huruf a KUHAP dan Pasal 167 KUHAP yang menghendaki kehadiran saksi secara fisik di ruang sidang. ${ }^{22}$ Di sisi lain, alat-alat bukti yang diberikan dalam proses persidangan online juga harus memberikan kepastian hukum terkait dengan keabsahan alat-alat bukti sesuai dengan Pasal 184 KUHAP.

Dalam persidangan online, tidak dapat menjamin bahwa alat-alat bukti yang digunakan dalam proses pembuktian tersebut adalah alat bukti yang benar-benar sesuai dengan peristiwa pidana sebagaimana yang telah terjadi. Alat bukti yang dimaksud tidak hanya dari JaksaPenuntut Umum tetapi juga setiap alat bukti yang

${ }^{20}$ Dian Erdianto, Eko Soponyono, "Kebijakan Hukum Pidana Dalam Pemberian Keterangan Saksi Melalui Media Teleconference Di Indonesia", Jurnal Law Reform, Volume 11, Nomor 1, Tahun 2015, hlm. 71.

${ }^{21}$ Wawancara dengan Reza Vahlefi Sohi Jaksa Penuntut Umum pada Kejaksaan Negeri Tangerang, tanggal 9 Juli 2020, Pukul 18:30 WIB, melalui percakapan online.

22 Swindy A.J. Tintingon, Op. Cit, hlm. 67. 
diserahkan oleh Penasihat Hukum atau Terdakwa. Dalam proses persidangan online ini memang mendukung anjuran pemerintah terkait physical distancing serta tidak terjadinya perkumpulan orang dengan massa yang banyak. Proses persidangan online ini juga memberikan kemudahan bagi para pihak dalam beracara karena tidak harus dalam satu ruangan yang sama dengan waktu yang ditentukan oleh Majelis Hakim.

Menurut Reza Vahlefi Sohi salah satu Jaksa Penuntut Umum yang bertugas pada Kejaksaan Negeri Tangerang dalam wawancara melalui percakapan online mengatakan persidangan online ini masih memiliki beberapa kelemahan seperti jaringan internet yang terbatas dan waktu persidangan yang berbeda dengan persidangan biasa dan hal itu mempengaruhi terhadap masa tahanan dari terdakwa serta sarana dan prasarana yang belum memadai untuk menunjang proses persidangan online secara maksimal. ${ }^{23}$ Kekuatan hukum pemeriksaan alat bukti saksi dengan cara telekonferensi tidak terlepas dari adanya terobosan hukum serta merupakan nilai-nilai hukum yang hidup di masyarakat berkaitan dengan perkembangan teknologi informasi. Keterangan melalui telekonferensi yang dijadikan sebagai alat bukti oleh Majelis Hakim tidak terlepas dari peran Hakim yang mengijinkan (melalui penetapannya) untuk melaksanakan telekonferensi. ${ }^{24}$

Proses persidangan online ini tidak terlepas dari Perjanjian Kerja Sama Antara Mahkamah Agung Republik Indonesia Nomor: 402/DJU/HM.01.1/4/2020, Kejaksaan Agung Republik Indonesia Nomor: KEP-17/E/Ejp/04/2020dan Kementerian Hukum Dan Hak Asasi Manusia Republik Indonesia Nomor: PAS08.HH.05.05 Tahun 2020 Tentang Pelaksanaan Persidangan Melalui Teleconference Pada Tanggal 13 April 2020. Hal tersebut juga didukung dengan dikeluarkannya SEMA No. 1 Tahun 2020 Pedoman Pelaksanaan Tugas Selama Masa Pencegahan Penyebaran Covid-19 di lingkungan Mahkamah Agung Republik Indonesia dan Badan Peradilan di bawahnya dan Surat Jaksa Agung Republik Indonesia Nomor B-049/A/Suja/03/2020 Tahun 2020 tentang Optimalisasi Pelaksanaan Tugas, Fungsi, Dan Kewenangan Ditengah Upaya Mencegah Penyebaran Covid-19. Idealnya pengaturan proses persidangan secara daring tak cukup hanya melalui perjanjian kerjasama, surat edaran institusi maupun Peraturan Mahkamah Agung.

${ }^{23}$ Wawancara dengan Reza Vahlefi Sohi Jaksa Penuntut Umum pada Kejaksaan Negeri Tangerang, tanggal 9 Juli 2020, Pukul 18:30 WIB, melalui percakapan online.

${ }^{24}$ Muhammad Ridho Wijaya, "Analisis Kekuatan Hukum Pemeriksaan Alat Bukti Saksi Dengan Cara Telekonferensi Dalam Persidangan Tindak Pidana Korupsi”, Fakultas Hukum Universitas Lampung, Bandar Lampung, 2019, hlm. 10. 
Namun dituangkan dalam KUHAP yang bakal direvisi. ${ }^{25}$

Hal ini menimbulkan permasalahan terkait payung hukum dalam pelaksanaan persidangan online saat ini. Dalam KUHAP sebagai dasar hukum utama proses acara pidana, tidak mengatur tentang persidangan online secara virtual seperti yang telah dilaksanakan belakangan ini. Mahkamah Agung, Kejaksaan Agung, Kemenkumham sepakat untuk melaksanakan persidangan online, hal ini bertolakbelakang dengan dasar hukum utama acara pidana dalam KUHAP. Hal ini berkaitan dengan hukum positif dan hukum progresif. Hukum positf hanya berpegang pada prinsip-prinsip hukum adalah perintah-perintah dari manusia (command of human being), tidak perlu ada hubungan antara hukum dengan moral, antara hukum yang ada (das sein) dengan hukum yang seharusnya (das sollen), analisis terhadap konsep-konsep hukum yang layak dilanjutkan dan harus dibedakan dari penelitian-penelitian historis mengenai sebab-sebab atau asal-usul dari undang-undang, serta berlainan pula dari suatu penilaian kritis, keputusankeputusan (hukum) dapat diskuksikan secara logis dari peraturan-peraturan yang sudah ada lebih dahulu, tanpa perlu menunjuk kepada tujuan-tujuan sosial, kebijaksanaan, dan moralitas, penghukuman (judgement) secara moral tidak dapat ditegakkan dan dipertahankan oleh penalaran rasional, pembuktian, atau pengujian. ${ }^{26}$

Hukum progresif mempunyai paradigma adalah bahwa "hukum adalah untuk manusia". Hukum sebagai pegangan, optik atau keyakinan dasar ini tidak melihat hukum sebagai sesuatu yang sentral dalam berhukum, melainkan manusialah yang berada di titik pusat perputaran hukum. Hukum ada untuk manusia, bukan manusia untuk hukum. Apabila kita berpegangan pada keyakinan, bahwa manusia adalah untuk hukum, maka manusia itu akan selalu diusahakan mungkin juga dipaksakan untuk bisa masuk ke dalam skema-skema yang telah dibuat oleh hukum. Hukum progresif menolak untuk mempertahankan status quo dalam berhukum. ${ }^{27}$

Bertahan dalam status quo memberi efek yang sama, seperti pada waktu orang berpendapat bahwa hukum adalah tolok ukur untuk semuanya dan manusia adalah

${ }^{25}$ Reda Mantovani, Menelisik Landasan Hukum Persidangan Perkara Pidana Secara Daring, https://www.hukumonline.com/berita/baca/lt5foed2e58d0d9/menelisik-landasan-hukum-persidanganperkara-pidana-secara-daring?page=all, (diterbitkan 15 Juli 2020).

${ }^{26}$ Najwan, J., Implikasi Aliran Positivisme Terhadap Pemikiran Hukum. INOVATIF Jurnal Ilmu Hukum, Volume 2, Nomor 3, Tahun 2010, hlm. 24.

27 Gede Made Swardhana, "Pergulatan Hukum Positivistik Menuju Paradigma Hukum Progresif", Masalah-Masalah Hukum, Volume 39, Nomor 4, Tahun 2010, hlm. 381. 
untuk hukum. Cara berhukum yang seperti itu sejalan dengan cara positivistik, normatik, dan legalistik. Ketika undang-undang mengatakan dan merumuskan seperti itu, kita tidak bisa berbuat banyak, kecuali hukumnya diubah terlebih dahulu. Peradaban hukum tertulis akan memunculkan sebab akibat sebagaimana dikemukakan di atas, maka cara kita berhukum sebaiknya juga mengantisipasi tentang bagaimana mengatasi hambatan-hambatan dalam menggunakan hukum tertulis. ${ }^{28}$

Cara berhukum yang lebih baik dan sehat dalam keadaan seperti itu adalah memberikan lorong-lorong untuk melakukan pembebasan dari hukum formal. Hukum progresif memberikan perhatian besar terhadap peranan perilaku manusia dalam hukum. Hal ini bertentangan dengan paradigma secara luas, bahwa hukum itu hanya urusan peraturan. Peranan manusia di sini merupakan konsekuensi terhadap pengakuan, bahwa sebaiknya kita tidak berpegangan secara mutlak kepada teks formal suatu peraturan. Cara berhukum yang penting untuk mengatasi stagnasi adalah dengan membebaskan diri dari dominasi yang membuat kepada teks undang-undang. Ciri atau karakteristik yang kuat dari hukum progresif terletak pada wataknya sebagai "hukum yang membebaskan". Dengan watak yang membebaskan itu, paham progresif sangat peka terhadap perubahan dan ide perubahan serta berkehendak kuat untuk membuat hukum menjadi suatu institut yang bersifat protagonis. ${ }^{29}$

Hukum itu tumbuh dan berkembang di tengah kehidupan masyarakat. Ketentuan KUHAP dengan Kesepakatan antara Mahkamah Agung, Jaksa Agung, dan Kementerian Hukum dan Hak Asasi Manusia merupakan dua hal yang bertentangan, seperti memilih terpaku dengan hukum positif atau bergerak dengan hukum progresif. Kondisi Pandemi Covid-19 "memaksa" Kesepakatan antara Mahkamah Agung, Jaksa Agung, dan Kementerian Hukum dan Hak Asasi Manusia menjadi dasar hukum sekaligus pedoman pelaksanaan persidangan online yang belum diatur dalam KUHAP. Dengan kondisi demikian, kita harus melenturkan kekakuan KUHAP karena pandemi bukan hanya trejadi di Indonesia tetapi juga di dunia dan ini berkaitan langsung dengan kehidupan masyarakat luas. Hal ini juga berkaitan dengan asas Lex Imperfecta, yang berarti hukum tanpa sanksi.

KUHAP menjadi dasar hukum utama bagi proses acara pidana, tetapi sifat dari peraturan hukum ini yaitu Lex Imperfecta atau kaidah hukum yang tidak memiliki sanksi. Oleh karena itu, pelaksanaan proses persidangan online menjadi

\footnotetext{
${ }^{28} \mathrm{Ibid}, \mathrm{hlm} .382$.

${ }^{29} \mathrm{Ibid}, \mathrm{hlm} .383$.
} 
hal yang krusial dan mendesak karena pandemi Covid-19 yang terjadi di luar kendali dari manusia. Peraturan hukum yang ada di dalam KUHAP sudah tidak relevan dengan kondisi kehidupan masyarakat yang terjadi saat ini, sebagimana adagium Het recht hink achter de feiten aan, yaitu hukum selalu tertinggal di belakang perkembangan zaman kehidupan manusia. Ketika hukum itu disahkan, maka sesungguhnya hukum itu sudah tertinggal dan kurang relevan bagi kehidupan masyarakat. Karena kehidupan masyarakat itu selalu berada di depan hukum itu sendiri.

Hukum Acara Pidana memang harus diubah dan futuristik, yaitu pembuatan rancangan undang-undang untuk saat ini harus dapat menjangkau kehidupan masyarakat yang akan datang dengan melihat kondisi kehidupan masyarakat saat ini yang sedang terjadi. Hal ini guna mengantisipasi setiap perilaku kehidupan masyarakat yang memungkinkan akan terjadi untuk beberapa tahun mendatang. Itulah yang menjadi alasan bahwa hukum hidup di tengah-tengah masyarakat dan hukum harus mengikuti kondisi kehidupan manusia yang terus berkembang termasuk kemajuan teknologi yang semakin cepat. Hukum tetap memiliki jati diri sebagai alat untuk mengatur kehidupan masyarakat dan memaksa pola kehidupan masyarakat itu sendiri karena hukum menjadi sebuah pedoman dan pegangan hidup untuk menjadi batasan dalam berperilaku dalam kehidupan sehari-hari.

Penerapan persidangan melalui Teleconference tidak terlepas juga dari proses pembuktian secara virtual yang akan dilakukan di masa mendatang. Dalam pasal 185 KUHAP mengatur tentang keterangan saksi dalam memberikan keterangan yang dinyatakan dalam persidangan, hal itu menjadi penting dari serangkaian alatalat bukti yang sah dalam persidangan. Keterangan beberapa orang saksi yang bediri sendiri-sendiri tentang suatu kejadian atau keadaan dapat digunakan sebagai suatu alat bukti yang sah apabila keterangan saksi itu ada hubungannya satu dengan yang lainnya sedemikian rupa, sehingga dapat dibenarkan adanya suatu kejadian atau keadaan tertentu. ${ }^{30}$ Pasal 185 KUHAP tidak mengatur tentang keterangan saksi secara video conference. Keabsahan dari keterangan saksi melalui Teleconference itu tidak diatur dalam pasal 185 KUHAP tersebut. Sebelum terjadinya pandemi Covid-19 seperti ini yang memaksa persidangan melalui Teleconference, sudah terlebih dahulu dilakukan pemeriksaan saksi melalui Teleconference pada saat pemeriksaan saksi atas nama B. J. Habibie yang berada di Hamburg, Jerman memberikan keterangan secara Teleconference di Pengadilan Negeri Jakarta Pusat

${ }^{30}$ Remincel, "Kedudukan Saksi Dalam Hukum Pidana", Ensiklopedia of Journal, Volume 1, Nomor 2, Tahun 2019, hlm. 270. 
dalam perkara kasus Bulog II pada tahun 2002 dan sidang perkara KTP elektronik menghadirkan saksi dari Singapura melalui Teleconference di Maxwell Chamber Gedung Arbitrase Singapura. ${ }^{31}$

Hal ini dilakukan atas permintaan Hakim yang meminta supaya keterangan saksi melalui Teleconference dilaksanakan guna mendukung pembuktian dalam mengungkap suatu perkara di persidangan. Di sisi lain keterangan saksi melalui Teleconference harus diantisipasi dari adanya peretas ilegal (hacker) dalam mengintervensi keterangan saksi dan menganggu jalannya proses persidangan acara pidana saat berlangsungnya pemeriksaan melalui Teleconference. Keamanan situs atau website yang digunakan oleh pengadilan harus memberikan jaminan serta kepastian hukum yang konkrit. Hal ini dapat memengaruhi keterangan saksi yang diberikan dan juga berdampak pada proses pembuktian suatu perkara.

Persidangan Teleconference ini dilakukan untuk pemenuhan kebutuhan teknologi yang semakin cepat dalam revolusi industri 4.0 serta menjadi upaya dari pelaksanaan physical distancing di masa pandemi Covid-19. Teknologi menjadi suatu hal yang membantu kehidupan masyarakat, tetapi harus sesuai dengan ketentuan prosedur yang tidak menyimpang sehingga kebenaran materiil itu dapat terpenuhi. Peraturan-peraturan hukum yang menaungi serta menjadi payung hukum harus memberikan kemanfaatan hukum bagi pelaksanaan persidangan melalui Teleconference ini sehingga dapat berjalan dengan maksimal.

\section{Kesimpulan}

a. Penerapan proses pembuktian dalam persidangan melalui Teleconference menjadi tantangan bagi Jaksa Penuntut Umum sebagai ahli pembuktian. Jaksa Penuntut Umum harus membuktikan setiap dakwaannya dengan didukung alat-alat bukti yang cukup dan sah meskipun dilakukan secara Teleconference. Hal ini menjadi rumit karena bergantung cukup besar terhadap jaringan internet yang stabil dan memadai. Dalam hal ini, diperlukan sarana dan prasarana bagi Hakim, JPU, Advokat/Terdakwa guna melaksanakan persidangan online dapat secara maksimal layaknya persidangan biasa. Sumber daya manusia yang mempuni juga diperlukan dalam proses persidangan melalui Teleconference untuk mengontrol dan mendukung kelancaran proses persidangan online agar dapat berjalan lancar.

31 Ruth Marina Damayanti Siregar, "Legalitas Keterangan Saksi Melalui Teleconference Sebagai Alat Bukti Dalam Perkara Pidana", Jurisprudence, Volume 5, Nomor 1, Maret Tahun 2015, hlm. 27. 
b. Pelaksanaan persidangan secara online ini lebih mengarah kepada hukum progresif yaitu keluar dari kekakuan KUHAP, yaitu berdasarkan Surat Edaran Mahkamah Agung, Surat Edaran Jaksa Agung, Peraturan Kemenkumham dan Kesepakatan dari Peradi, tetapi tetap berpedoman pada KUHAP. Dalam proses pembuktian di masa mendatang perlu adanya keamanan situs atau website khusus yang digunakan dalam pelaksanaan persidangan melalui Teleconference guna mengantisipasi adanya peretas ilegal (hacker) yang dapat mengintervensi pemeriksaan keterangan saksi dan menganggu jalannya proses persidangan pidana khususnya dalam pembuktian.

\section{Daftar Pustaka}

\section{A. Buku}

Afitra. (2017). Hukum Pembuktian Dalam Beracara Pidana, Perdata dan Korupsi di Indonesia - Cet.4. Jakarta. Raih Asa Sukses.

Hamzah, A. (2010). Asas-Asas Hukum Pidana edisi revisi 2008. Jakarta. Rineka Cipta.

Hiariej, E. O. S., (2012). Teori \& Hukum Pembuktian. Jakarta. Erlangga.

Sasangka, H., Rosita, L., (2003). Hukum Pembuktian Dalam Perkara Pidana (Untuk Mahasiswa dan Praktisi). Bandung. Mandar Maju.

Rit, M. N. M., Putra, I. B. W., (2019). Keabsahan Pemeriksaan Saksi Melalui Teleconference Dalam Sidang Tindak Pidana Korupsi. Program Kekhususan Peradilan Fakultas Hukum Universitas Udayana.

Wijaya, M. R., (2019). “Analisis Kekuatan Hukum Pemeriksaan Alat Bukti Saksi Dengan Cara Telekonferensi Dalam Persidangan Tindak Pidana Korupsi". Fakultas Hukum Universitas Lampung. Bandar Lampung.

\section{B. Peraturan Peundang-undangan}

Undang-Undang Nomor 8 Tahun 1981 tentang Hukum Acara Pidana atau KUHAP, Lembaran Negara Republik Indonesia Tahun 1981 Nomor 76 dan penjelasannya yang dimuat dalam Tambahan Lembaran Negara Republik Indonesia Nomor 3209.

Perjanjian Kerja Sama Antara Mahkamah Agung Republik Indonesia Nomor: 402/DJU/HM.01.1/4/2020, Kejaksaan Agung Republik Indonesia Nomor: KEP-17/E/Ejp/04/2020dan Kementerian Hukum Dan Hak Asasi Manusia Republik Indonesia Nomor: PAS-08.HH.05.05 Tahun 2020 Tentang Pelaksanaan Persidangan Melalui Teleconference.

Surat Edaran Mahkamah Agung RI Nomor: 1 Tahun 2020. Tanggal 23 Maret 2020.

Tentang Pedoman Pelaksanaan Tugas Selama Masa Pencegahan 
Penyebaran Corona Virus Disease 2019 (COVID - 19) di Lingkungan Mahkamah Agung RI dan Badan Peradilan Berada di Bawahnya.

Surat Jaksa Agung Republik Indonesia Nomor B-049/A/Suja/03/2020 Tahun 2020 tentang Optimalisasi Pelaksanaan Tugas, Fungsi, Dan Kewenangan Ditengah Upaya Mencegah Penyebaran Covid-19.

\section{Artikel Jurnal}

Dian, E., Soponyono, E., "Kebijakan Hukum Pidana Dalam Pemberian Keterangan Saksi Melalui Media Teleconference Di Indonesia". Jurnal Law Reform, Volume 11, Nomor 1, Tahun 2015.

Jemmy, M., “Tinjauan Yuridis Tentang Pemeriksaan Saksi Dipersidangan Melalui Teleconference". Jurnal Ilmu Hukum Legal Opinion, Volume 1, Nomor 4 Tahun 2013.

Murniasih, S., "Pembuktian Berdasar Keterangan Saksi Verbalisan Akibat Pencabutan Keterangan Terdakwa Di Persidangan Dalam Perkara Persetubuhan Terhadap Anak (Studi Putusan Pengadilan Negeri Brebes Nomor 27/Pid.Sus/2016/Pn.Bbs)", Jurnal Verstek, Volume 7, Nomor 2, Bagian Hukum Acara Universitas Sebelas Maret.

Najwan, J., Implikasi Aliran Positivisme Terhadap Pemikiran Hukum. INOVATIF | Jurnal Ilmu Hukum, Volume 2, Nomor 3, Tahun 2010.

Nugroho, B., "Peranan Alat Bukti Dalam Perkara Pidana Dalam Putusan Hakim Menurut Kuhap". Yuridika. Volume 32, Nomor 1, Tahun 2017.

Remincel., "Kedudukan Saksi Dalam Hukum Pidana”, Ensiklopedia of Journal, Volume 1, Nomor 2, Tahun 2019.

Siregar, R. M. D., “Legalitas Keterangan Saksi Melalui Teleconference Sebagai Alat Bukti Dalam Perkara Pidana". Jurisprudence, Volume 5, Nomor 1, Tahun 2015.

Swardhana, G. M., "Pergulatan Hukum Positivistik Menuju Paradigma Hukum Progresif". Masalah-Masalah Hukum, Volume 39, Nomor 4, Tahun 2010.

Tintingon, S. A. J., “Kesaksian Saksi Melalui Teleconference Dalam Persidangan Di Pengadilan". Lex et Societatis, Volume 2, Nomor 8, Tahun 2014.

\section{Internet dan Sumber Lainnya}

Mantovani, R., Menelisik Landasan Hukum Persidangan Perkara Pidana Secara Daring, https://www.hukumonline.com/berita/baca/lt5f0ed2e58d0d9/menelisiklandasan-hukum-persidangan-perkara-pidana-secara-daring?page=all, (diterbitkan 15 Juli 2020).

Sohi, R. V., Jaksa Penuntut Umum pada Kejaksaan Negeri Tangerang, Wawancara tanggal 9 Juli 2020. 